\title{
Central Giant Cell Granuloma of the J aws: A Short Series and Review of Literature
}

\author{
${ }^{1}$ SK Mathur, ${ }^{2}$ Parveen Rana Kundu, ${ }^{3}$ Sugandha Mohan, ${ }^{4}$ Virender Singh \\ ${ }^{1}$ Director, Professor, Department of Pathology, Postgraduate Institute of Medical Sciences, Rohtak, Haryana, India \\ ${ }^{2}$ Senior Resident, Department of Pathology, Postgraduate Institute of Medical Sciences, Rohtak, Haryana, India \\ IIntern, Government Dental College and Hospital, Rohtak, Haryana, India \\ ${ }^{4}$ Professor and Head, Department of Oral and Maxillofacial Surgery, Government Dental College and Hospital, Rohtak, Haryana, India
}

Correspondence: Parveen Rana Kundu, Senior Resident, Department of Pathology, Pt BD Sharma PGIMS, Rohtak-124001 Haryana, India, Phone: 911262 213905, e-mail: zskundu2003@ rediffmail.com

\section{ABSTRACT}

Introduction: Central giant cell granuloma (CGCG) accounts for less than $7 \%$ of all lesions of the jaw. It occurs more commonly in the anterior mandible compared to the maxilla. Females have 2 to 3 times higher incidence. Children and young adults are affected the most.

Materials and methods: The present series reviews 10 cases of CGCG suspected on clinical and radiologic basis and confirmed by histopathologic examination.

Results: The age of 10 cases ranged from 7 to 32 years (mean age 19.8); there were six females and four males; six had lesion in the lower jaw and the remaining four in the upper jaw. After radiologic evaluation, the treatment involved surgical curettage which was subjected to histopathologic examination and diagnosed as CGCG.

Conclusions: CGCG is diagnosed by a combination of clinical and radiologic findings and confirmed by histopathology. The condition needs to be distinguished from other giant cell containing lesions. The early and precise diagnosis of CGCG allows conservative management with minimal risk to the adjacent tooth or bone.

Keywords: Central giant cell granuloma, Peripheral giant cell granuloma, Reparative granuloma, Mandible, Maxilla, J aw.

\section{INTRODUCTION}

Giant cell granuloma (GCG) as an entity was first introduced by J affé ${ }^{1}$ in 1953 to distinguish it from giantcell tumor (GCT) of the bone. He established two pathological entities in this regards, the central giant cell granuloma (CGCG) arising within the bone and the peripheral giant cell granuloma (PGCG) arising in the soft tissues. CGCG, also termed as reparative giant cell granuloma, is an uncommon benign intraosseus lesion that occurs most often in the jaws-more so in the mandible than the maxilla, and much less often at extragnathic sites. $^{2,3}$ Etiopathogenesis of these lesions has remained unclear-some consider them as reparative response rather than neoplastic condition while others consider them as neoplastic with potential to progress sometimes. ${ }^{4-6}$ However, their histology and clinical behavior have been studied in depth.

The CGCG of the jaw accounts for approximately $7 \%$ of all tumors of the jaw. ${ }^{5}$ It may occur at any age but is more commonly seen in the first three decades of life. ${ }^{6}$ The usual clinical presenting feature is of a painful or painless red purple nodule located in the region of gums or edentulous al veolar margins. A pproximately one-third of the CGCGs are located in the anterior mandible in the incisor, canine and premolar regions. ${ }^{5}$ CGCG of the jaw is usually unifocal and has traditionally been treated surgically, the common therapy being curettage or resection. ${ }^{7}$ The clinical behavior of CGCG varies from a slow-growing asymptomatic swelling to an aggressive lesion that manifests with pain, cortical perforation and root resorption. ${ }^{8}$

The present short series of CGCG highlights the clinicoradiologic aspects and emphasizes the role of histopathology in its differential diagnosis from other morphologically similar conditions and in determining its clinical behavior.

\section{MATERIALS AND METHODS}

The study was conducted jointly by the D epartment of Pathology, PtBD Sharma PGIMS, and D epartment of Oral and M axillofacial Surgery, Government Dental College and Hospital, Rohtak, by retrieving archival case records and histopathologic slides of all cases diagnosed as CGCG of the upper or lower jaw during the preceding 2 years. A total of 10 cases were accessioned during this period. Their clinical features were compiled and radiologic/ CT findings recorded. Slides of biopsies submitted in each case were reviewed and special stains (such as Perl's stain for iron, $M$ asson's trichrome and V an Gieson for collagen, Verhoeff's for elastic fibers) were done, wherever required.

\section{RESULTS}

The clinical profile and radioimaging features of the patients are given in Table 1. The age of patients ranged from 7 to 32 years (mean age 19.8 years) with mal e: femal e ratio of $2: 3$. In six cases, thelesion was located in the mandibular region whilemaxillawas 
Table 1: Clinical profile and radiological features of cases of CGCG $(n=10)$

\begin{tabular}{|c|c|c|c|c|c|c|}
\hline Case no. & Age/sex & $\begin{array}{l}\text { Location of } \\
\text { lesion }\end{array}$ & Duration & Clinical features & $\begin{array}{l}\text { Clinical } \\
\text { diagnosis }\end{array}$ & Imaging features \\
\hline 1 & $30 / F$ & $\begin{array}{l}\text { Left maxillary anterior } \\
\text { region }\end{array}$ & 4-5 months & $\begin{array}{l}\text { Painless, soft, pedunculated } \\
\text { swelling, recentincrease in size }\end{array}$ & Odontogenic cyst & $\begin{array}{l}\text { IOPA: Periapical } \\
\text { pathology wrt } \\
\text { tooth number } \\
\quad 123\end{array}$ \\
\hline 2 & $18 / \mathrm{M}$ & $\begin{array}{l}\text { Left mandibular anterior } \\
\text { region }\end{array}$ & 5 months & $\begin{array}{l}\text { Painless, pedunculated, soft } \\
\text { tissue overgrowth, size } 1 \times 2 \mathrm{~cm}\end{array}$ & Ameloblastoma & $\begin{array}{l}\text { IOPA: } \\
\text { Involvement of } \\
\text { tooth number } \\
=\frac{1}{\mid 123}\end{array}$ \\
\hline 3 & $20 / F$ & $\begin{array}{l}\text { Right maxillary palatal } \\
\text { region }\end{array}$ & 4 months & $\begin{array}{l}\text { Diffuse, nontender hard } \\
\text { swelling, causing expansion } \\
\text { of bone }\end{array}$ & $\begin{array}{l}\text { Benign odonto- } \\
\text { genic tumor }\end{array}$ & $\begin{array}{l}\text { Occlusal view: } \\
\text { Multilocular } \\
\text { lesions on right } \\
\text { side of palate in } \\
\frac{7-4 \mid}{1} \text { region }\end{array}$ \\
\hline 4 & $19 / F$ & $\begin{array}{l}\text { Right maxillary gingival } \\
\text { region }\end{array}$ & $\begin{array}{l}1-1.5 \\
\text { months }\end{array}$ & Painless, nontender swelling & $\begin{array}{l}\text { Giant cell } \\
\text { granuloma }\end{array}$ & $\begin{array}{l}\text { IOPA: } \\
\text { Multilocular } \\
\text { lesion with bony } \\
\text { trabeculae in } \\
\text { right maxilla with } \\
\text { bony expansion }\end{array}$ \\
\hline 5 & $32 / F$ & $\begin{array}{l}\text { Left posterior } \\
\text { mandibular region }\end{array}$ & 6 months & $\begin{array}{l}\text { Bony hard swelling, slightly } \\
\text { tender on palpation }\end{array}$ & Ameloblastoma & $\begin{array}{l}\text { OPG : A } \\
\text { radiolucent } \\
\text { lesion with slight } \\
\text { radiopacity in } \\
\text { center of the } \\
\text { lesion extending } \\
\text { from } \\
\text { region | } 5-8\end{array}$ \\
\hline 6 & $7 / M$ & $\begin{array}{l}\text { Right mandibular } \\
\text { posterior region }\end{array}$ & 1 month & $\begin{array}{l}\text { Firm, hard swelling, subsides } \\
\text { on taking medication; } \\
\text { nontender on palpation }\end{array}$ & Neoplastic lesion & $\begin{array}{l}\text { OPG: Radiolucent } \\
\text { lesion with } \\
\text { irregular margins } \\
\text { in right } \\
\text { mandibular } \\
\text { posterior region }\end{array}$ \\
\hline 7 & $25 / M$ & $\begin{array}{l}\text { Left mandibular buccal } \\
\text { vestibule }\end{array}$ & 6 months & $\begin{array}{l}\text { Nontender, pedunculated, } \\
\text { erythematous mass, not fixed } \\
\text { to the underlying structures }\end{array}$ & Fibroma & $\begin{array}{l}\text { OPG: Mass } \\
3 \times 3.6 \mathrm{~cm} \text { wrt } \\
\frac{1}{345}\end{array}$ \\
\hline 8 & $10 / F$ & Right mandibular region & 2 months & Pain and swelling & Myxofibroma & $\begin{array}{l}\text { OPG: Radiolucent } \\
\text { lesion with } \\
\text { irregular margins }\end{array}$ \\
\hline 9 & $15 / M$ & Maxillary anterior region & 3 months & $\begin{array}{l}\text { Pain, swelling in upper } \\
\text { front teeth }\end{array}$ & $\begin{array}{l}\text { Fibro-osseous } \\
\text { lesion }\end{array}$ & $\begin{array}{l}\text { CT: A fibro- } \\
\text { osseous lesion } \\
\text { present as } \\
\text { swelling in the } \\
\text { labial vestibule }\end{array}$ \\
\hline 10 & $22 / F$ & $\begin{array}{l}\text { Right mandibular } \\
\text { vestibule from premolar } \\
\text { to molar region }\end{array}$ & 20 Days & Pain, swelling & Giant cell tumor & $\begin{array}{l}\text { OPG: } \\
\text { Multilocular } \\
\text { well-defined } \\
\text { noncorticated } \\
\text { radiolucent } \\
\text { lesion }\end{array}$ \\
\hline
\end{tabular}

IOPA: Intraoral periapical X-ray; OPG: Orthopantogram; CT: Computed tomography 


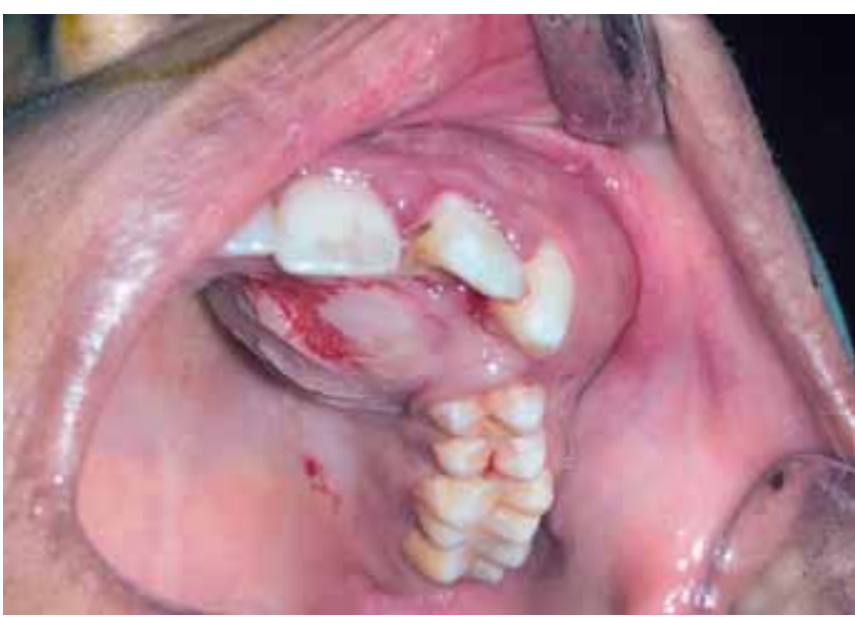

Fig. 1: Clinical appearance of lesion on left side of the palate in maxillary anterior region

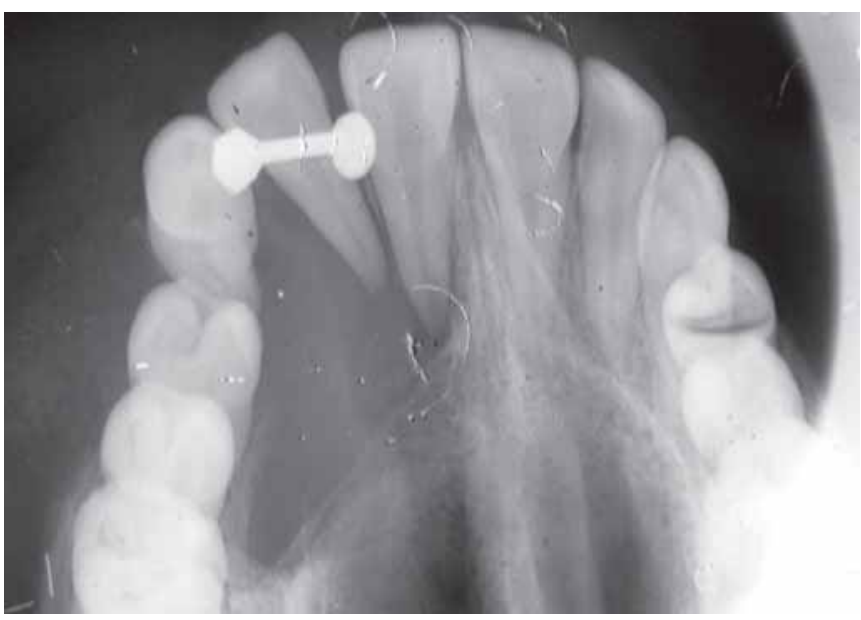

Fig. 2: Postoperative radiograph showing radiopacity in region after enucleation of lesion

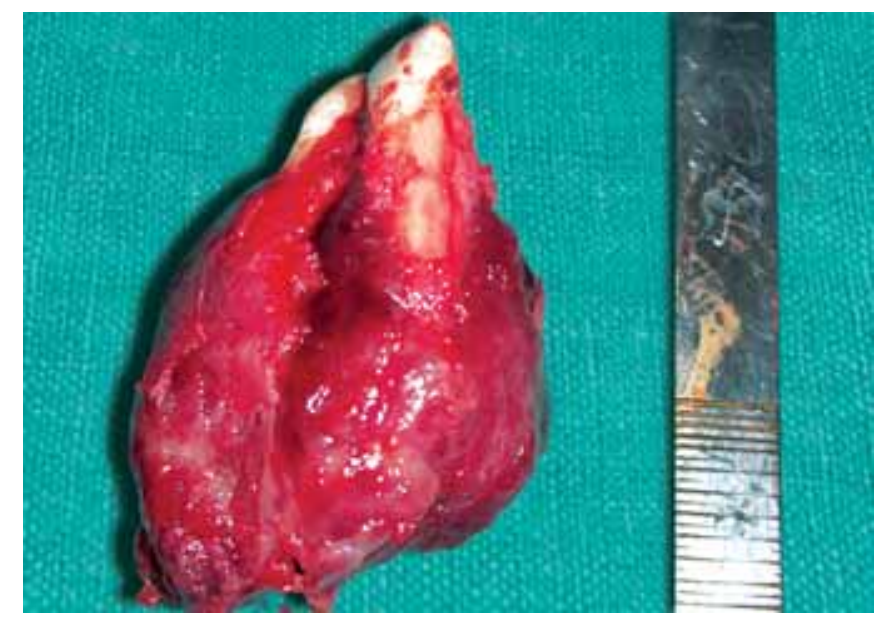

Fig. 3: Gross appearance of excised lesion, posterior view. The lesion measured $2 \times 1 \mathrm{~cm}$ in size and was grayish-white and hemorrhagic

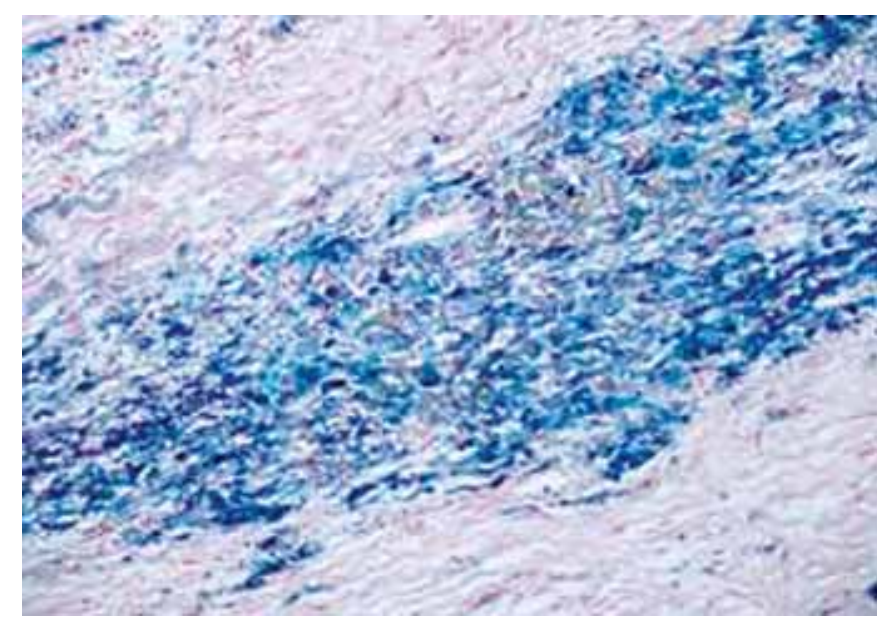

Fig. 4: Perl's stain to demonstrate hemosiderin pigment as Prussian blue color (x200)

Table 2: Detailed histopathologic features of cases of CGCG $(n=10)$

$\begin{array}{rllllll}\text { Case no. } & \text { Stromal cells } & \text { Giant cells } & \text { Vascularity } & \text { Hemorrhage } & \text { Hemosiderin-histiocytes } & \text { Mitosis } \\ 1 & \text { Bland fibroblasts } & +++ & \text { Moderate } & \text { Present } & ++ & - \\ 2 & \text { Plump fibroblasts } & ++ & \text { Moderate } & \text { Present } & ++ & - \\ 3 & \text { Bland fibroblasts } & ++ & \text { Moderate } & \text { Present } & ++ & - \\ 4 & \text { Young fibroblasts } & ++ & \text { Moderate } & \text { Present } & ++ & - \\ 5 & \text { Collagen } & + & \text { Less } & \text { Little } & ++ & + \\ 6 & \text { Plump fibroblasts } & ++ & \text { Rich } & \text { Present } & ++ & + \\ 7 & \text { Collagen } & + & \text { Less } & \text { Absent } & ++ & - \\ 8 & \text { Plump fibroblasts } & ++ & \text { Moderate } & \text { Present } & ++ & - \\ 9 & \text { Bland fibroblasts } & +++ & \text { Moderate } & \text { Present } & + & -\end{array}$

the site of involvement in remaining four cases. M ost of the patients presented with painless swelling $(60 \%)$ in the upper or lower jaw, insidiously growing over a period ranging from 20 days to 6 months (Fig. 1). Therewas no history of trauma or any systemic or local infection in any case. Tooth displacement and mobility were notevidentin thesamequadrant. Orthopantogram (OPG) and intraoral periapical (IOPA) radiographs were done in all cases, with computed tomograghy (CT) scan was done in a single case, in addition. The radiological findings revealed solitary well-defined, Iytic, expansile and multilocular radiolucentlesion (Fig. 2). Therewas rootresorption of adjacent teeth. However, there was no evidence of sclerosis or internal calcification and the matrix appeared clear. CT scan of one patient reveal ed afibro-osseous lesion on thelabial vestibuleintheregion of maxillary anterior teeth. R outinelaboratory investigations did not show any abnormality in any case. 


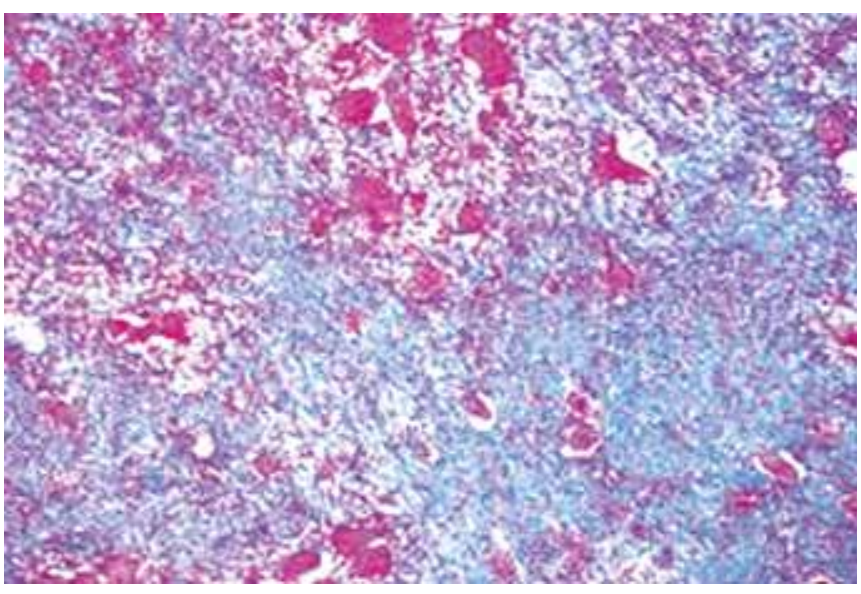

Fig. 5: Masson's trichrome stain showing blue color of collagen in the older lesion $(\times 200)$

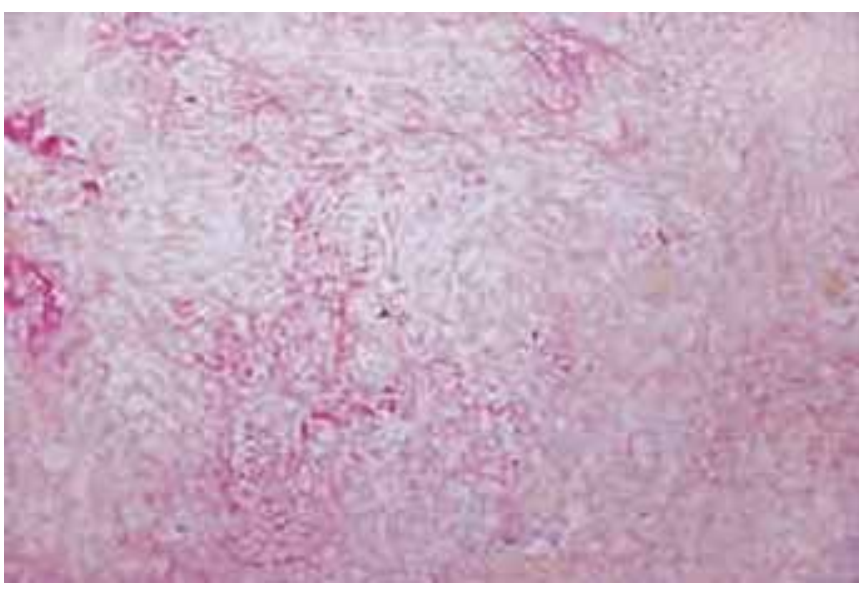

Fig. 6: Van Gieson stain imparts reddish color to collagen $(\times 200)$

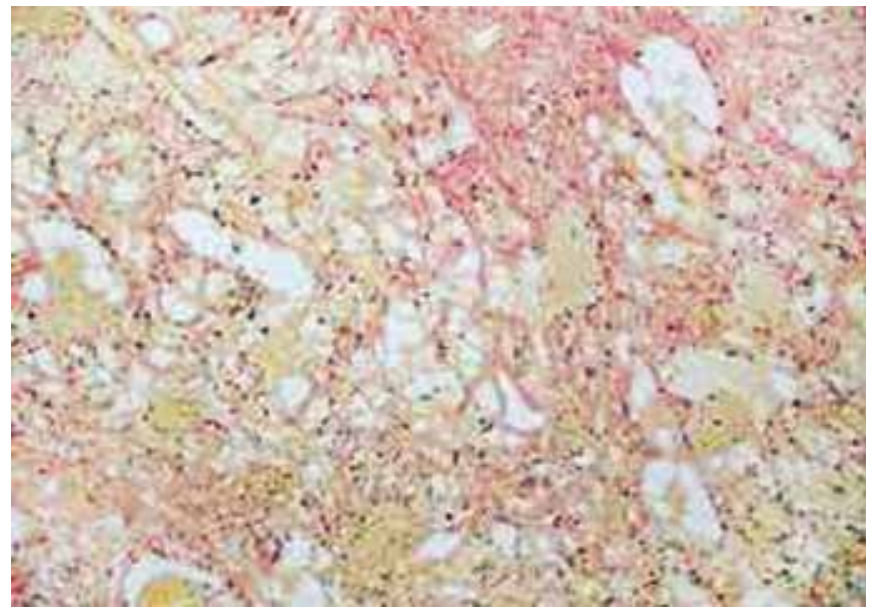

Fig. 7: Verhoeff's stain gives black color to elastic tissue $(\times 200)$
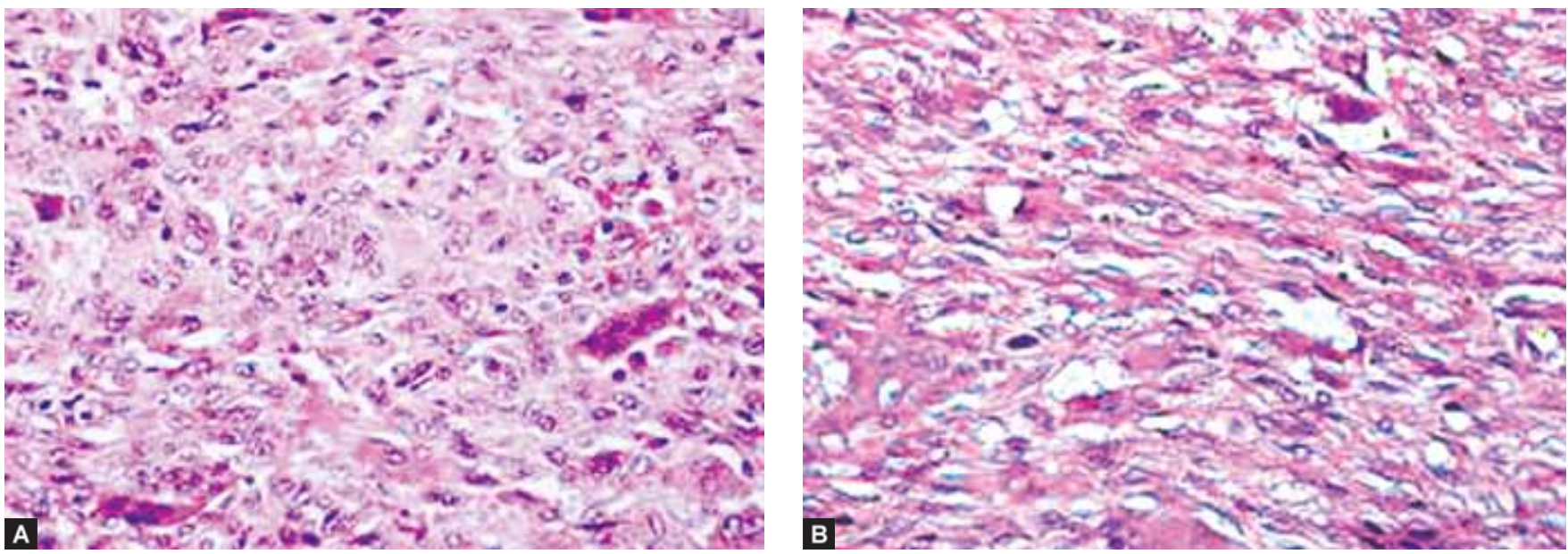

Figs 8A and B: (A) Stromal cells are plump but benign (hematoxylin and eosin, $\times 400$ ). (B) Stromal cells in older lesion show hypocellular collagen (hematoxylin and eosin, $x 400$ )

Surgical curettage was done in all the cases and submitted for histopathology (Fig. 3). Detailed histopathological features are summarized in Table 2. Special stains done in some cases included Perl's (Fig. 4), M asson's trichrome (Fig. 5), Van Gieson (Fig. 6) and Verhoeff's stain (Fig. 7). The parameters for histopathologic eval uation taken into consideration included stromal cells (bland or plump fibroblasts to hypocellular collagen) (Figs $8 \mathrm{~A}$ and $\mathrm{B}$ ), multinucleate giant cells $(+$ to +++$)$ (Figs $9 A$ and $B$ ), vascularity (less to rich) (Figs $10 A$ and $B$ ), hemosiderin-laden macrophages (+ to +++) (Fig. 11) and mitoses (- or +) (Fig. 12). B ased on these parameters, it was found that none of the 10 cases had abnormal mitotic activity. 

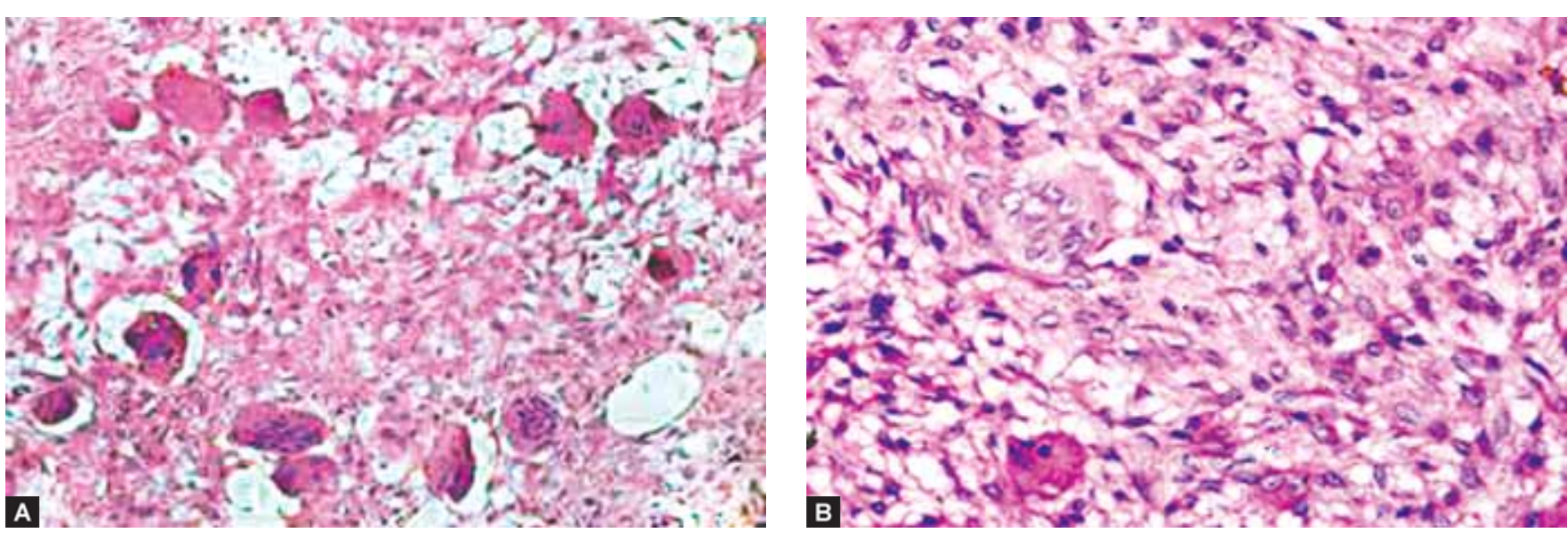

Figs 9A and B: (A) Numerous multinucleate cells $(4+)$ are seen in this photomicrograph (hematoxylin and eosin, $\times 200$ ). (B) A few giant cells lying in the background of benign stroma graded as $1+($ hematoxylin and eosin, $\times 200)$
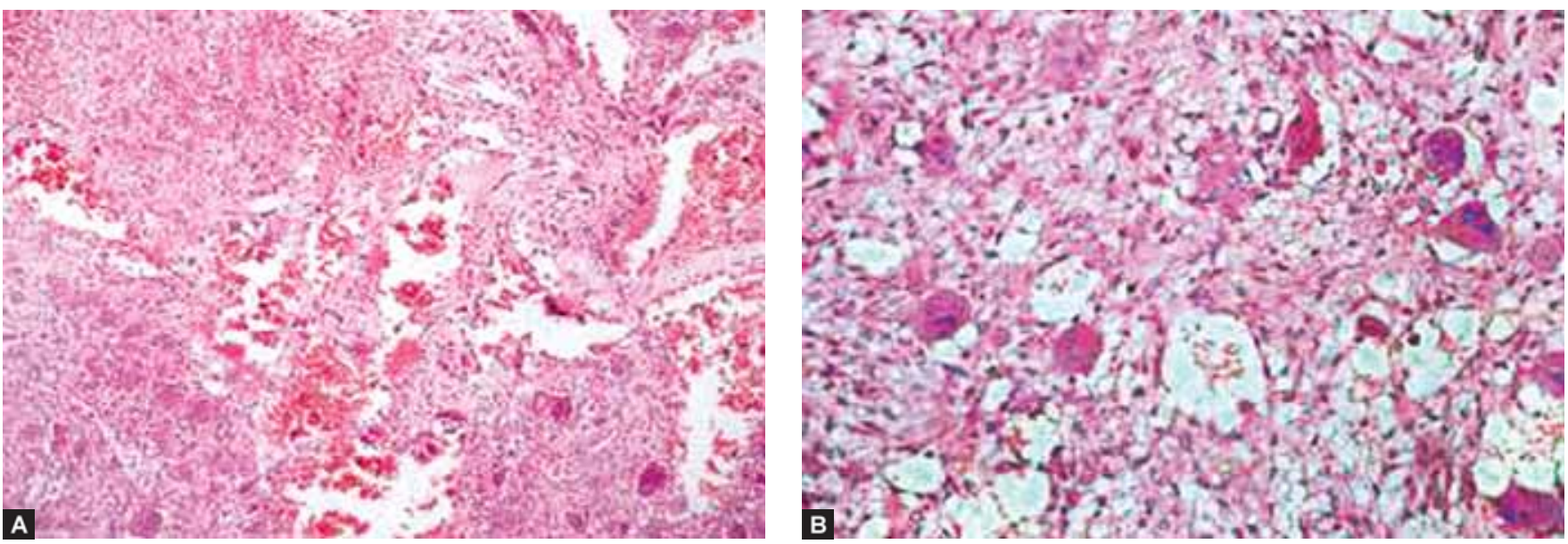

Figs 10A and B: (A) The filed shows rich vasculartiy of the lesion (hematoxylin and eosin, $\times 200$ ).

(B) Only a few vascular channels are seen (hematoxylin and eosin, $\times 200$ )

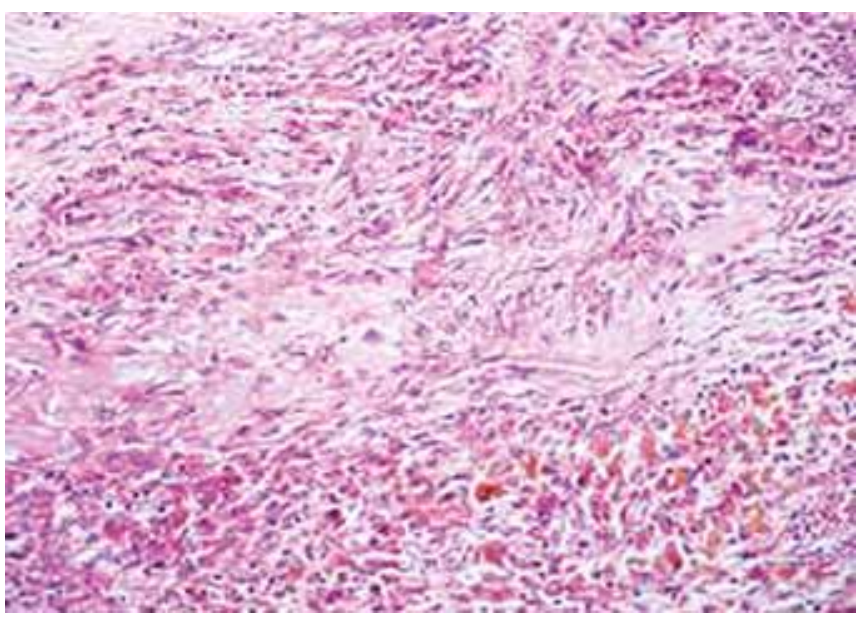

Fig. 11: Numerous hemosiderin-laden macrophages identified by golden-brown color are seen (4+) (hematoxylin and eosin, $\times 200$ )

Hypocelluar collagen was noticeable in two cases and in both these cases the duration of symptoms was 6 months. However, no significant correlation could be drawn between other microscopic parameters and clinicoradiological findings. The final report in all cases was consistent with the diagnosis of central giant cell granuloma. Postoperative clinical follow-up

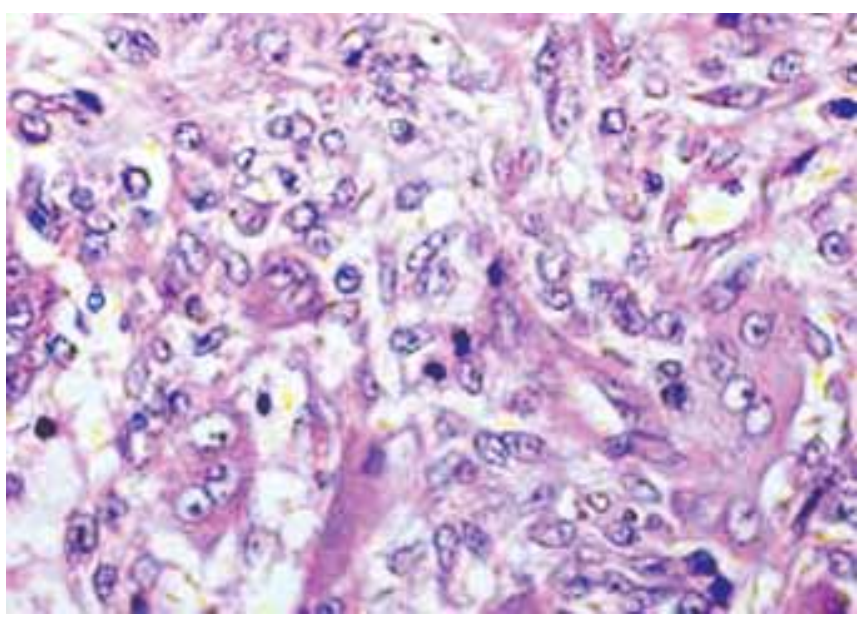

Fig. 12: A few mitotic figures are present in the stroma graded as $3+$ (hematoxylin and eosin, $x 400$ )

for more than one year in all cases was uneventful and all teeth were vital to electric and thermal pulp testing.

\section{DISCUSSION}

CGCG is an intraosseous lesion occurring predominantly in teens and adults. A round two-third cases are diagnosed in 
patients less than 30 years of age. ${ }^{9}$ The results of present study showed 19.8 years as mean age. In conformity with other literature reports, ${ }^{10}$ femal es were affected more often than males in our study too; six out of 10 cases in this study were females. A few workers have assigned female preponderance of CGCG to increased levels of estrogen in these patients. ${ }^{11,12}$

The mandible or lower jaw is the preferred site for CGCG, with alveolar processes of the premolar and molar regions being the most common location. ${ }^{13}$ Of our 10 cases, six were located in the edentulous al veolar margins of the premolar region, and tw 0 each in pal atal region and in attached gums between upper incisors with palatal extension. Clinically, majority of cases are asymptomatic while the aggressive ones may present with pain, swelling, root resorption, cortical perforation and/or recurrence. ${ }^{14}$ In a study by K ruse-L osser et al, ${ }^{15} 16$ out of 26 patients were asymptomatic. In our study, none of the cases presented with clinical features of aggressive behavior or recurrence after one year of follow-up.

There have been several studies on radiological evaluation of CGCG and have shown unilocular areas of lucency in small early lesions while later multilocular lucency develops. ${ }^{16-19} \mathrm{In}$ our study, multilocularity was observed in three out of 10 cases and these w ere relatively larger lesions $(>1.5 \mathrm{~cm}$ ) while others varied from 0.5 to $1.5 \mathrm{~cm}$ in diameter. Duration of symptoms in three cases having larger lesions ranged from 4 to 6 months.

Histologically, the W orld $\mathrm{H}$ eal th $\mathrm{O}$ rganization has defined giant cell granuloma as 'a localized benign but sometimes aggressive osteolytic proliferation consisting of fibrous tissue with hemorrhage and hemosiderin deposits, presence of osteoclast-like giant cells and reactive bone formation' ${ }^{20}$ On histopathology, CGCG exhibits a wide spectrum of features and a highly vascular and cellular granul ation tissue containing irregularly scattered multinucleate giant cells of foreign body type and mitoses in the stromal cells. Extravasation of red blood cells with hemosiderin and occasional bone formation may be seen. ${ }^{6}$

A number of other giant cell rich lesions in the jaw enter into the differential diagnoses. These include giant cell tumor, cherubism, aneurysmal bone cyst, traumatic bone cyst and jaw tumor of hyperparathyroidism. ${ }^{21}$ Their relationship to each other, however, is ill-defined. In cherubism, focal arrangements of giant cells within a vascular stroma with thin-walled capillaries adjacent to the giant cells are of note. The absence of perivascular cuffing can help differentiate CGCG from cherubism. Presence of foreign body type giant cells and absence of stromal tumor cells differentiate CGCG from a GCT. Solid aneurysmal bone cyst has large blood spaces. Normal serum calcium, parathyroid hormone, al kal ine phosphatase and phosphorous levels distinguish CGCG from brown tumor of hyperparathyroidism. ${ }^{2}$ In rare cases, giant cell granulomas are an oral manifestation of hyperparathyroidism. The latter can be suspected when multiple lesions are identified and the patient suffers recurrences despite adequate treatment.

Although the etiology of CGCG is not quite clear, many authors consider the origin to comprise an abnormal proliferative response to aggression. ${ }^{5}$ Considering that CGCG is not a true neoplasm but is rather a benign hyperplastic reactive lesion caused by local irritation or chronic trauma, different local causal factors have been implicated that include complicated dental extractions, dental restorations in poor conditions, food impaction (dental mal positioning), plaque and tartar, etc. ${ }^{22,23}$ Despite the fact that the course of the disease is considered benign, some documented cases of metastases exist in the literature. ${ }^{24} \mathrm{M}$ alignant transformations to osteosarcoma or fibrosarcoma have also been reported. ${ }^{25}$

Theconservativesurgical treatmentis themostaccepted and traditional form of treatment of CGCG, usually involving curettage alone or along with peripheral ostectomy. ${ }^{2}$ Radical surgical techniques of resection without continuity defect and peripheral ostectomy and enblocresection havesometimes been justified for aggressive CGCG. ${ }^{8}$ Incidence of recurrence after surgery is 4 to $20 \%$, whereas locally aggressive giantcell lesions have a higher recurrence rate and it usually occurs due to incomplete removal of the lesion. None of our cases reported recurrence after oneyear of follow-up. N onsurgical approaches likechemical cautery, electrocautery, cryotherapy havebeen used and newer therapies like calcitonin, interferon al pha and intralesional steroids are being used to avoid disfigurement. ${ }^{26-30}$

\section{REFERENCES}

1. Jaffe HL. Giant cell reparative granuloma, traumatic bone cyst, and fibrous (fibro-osseous) dysplasia of the jaw bones. O ral Surg Oral Med Oral Pathol 1953;6(1):159-75.

2. Pogrel MA. Benign nonodontogenic lesions of the jaws. In: Peterson's principles of oral and maxillofacial surgery (2nd ed). M iloro M, Ghali GE, Larsen PE, W aite PD (Eds). London: BC Decker Inc 2004;1:597-616.

3. Regezi JA. Odontogenic cysts, odontogenic tumors, fibroosseous, and giant cell lesions of the jaws. M od Pathol 2002;15(3):331-41.

4. Ustundag $E$, I seri M, K eskin G, M uezzinoglu B. Central giant cell granuloma. Int J Pediatr Otorhi 2002;65(2):143-46.

5. K fir Y, B uchner A, Hansen L. R eactive lesions of the gingiva: A clinicopathological study of 741 cases. J Periodontol 1980; 51:655-61.

6. A ndersen L, Fejerskov O, Philipsen HP. Oral giant cell granulomas: A clinical and histological study of 129 new cases. Acta Pathol Microbiol Scand 1973;81:606-16.

7. Bataineh AB, AI-K hateeb $T, R$ awashdeh $M A$. The surgical treatment of central giant cell granuloma of the mandible. J Oral M axil Surg 2002;60(7):756-77.

8. Chuong R, Kaban LB, K ozakewich H, Perez-A tayde A. Central giant cell lesions of the jaws: A clinicopathologic study. J Oral Maxil Surg 1986;44(9):708-13.

9. A nclair PL, A rendt DM , Hellstain JW. Giant cell lesions of the jaws. Oral M axillofac Surg Clin N Am 1997;9:655-80.

10. Waldron $C A$, Shafer $W G$. The central giant cell reparative granul oma of the jaws: A $n$ analysis of 38 cases. A m J Clin Pathol 1966;45:437-47.

11. FlaggertJ S, HeldtLV , Gareis FJ. Recurrent giant cell granuloma occurring in the mandible of a patient on high dose estrogen therapy for the treatment of Sotos' syndrome. J O ral M axillofac Surg 1987;45:1074-76. 
12. Littler BO. Central giant cell granul oma of the jaw-a hormonal influence. Br J Oral Surg 1980;17:43.

13. Shafer W G, Hine M K, Levy BM . A textbook of oral pathology. Igaku-Shoin: W B Saunders Company 1983;146-49.

14. Whitaker SB, Waldron CA. Central giant cell lesions of the jaws: A clinical, radiologic and histopathologic study. Oral Surg Oral Med Oral Pathol 1993;75(2):199-208.

15. Kruse-Lösler B, Diallo R, Gaertner $C$, Mischke $K L$, Joos U, K leinheinz J. Central giant cell granul oma of the jaws: A clinical, radiologic, and histopathologic study of 26 cases. Oral Surg Oral Med Oral Pathol Oral Radiol Endod 2006;101(3): 346-54.

16. Cohen M A, Hertzanu $Y$. Radiologic features, including those seen with computed tomography, of central giant cell granuloma of the jaws. Oral Surg Oral M ed Oral Pathol 1988;65:255-61.

17. Kaffe I, Ardekian L, Taicher S, Littner M M, Buchne A. Radiologic features of central giant cell granuloma of the jaws. Oral Surg Oral M ed Oral Pathol Oral Radiol Endod 1996;81:720.

18. Scholl RJ, Kellett HM, Neumann PD, et al. Cysts and cystic lesions of the mandible: Clinical and radiologic-histopathologic review. Radiographics 1999;19:1107-24.

19. M ark D, M urphey M D, G eorge C, et al. Imaging of giant cell tumor and giant cell reparative granuloma of bone: Radiologicpathologic correlation. Radiographics 2001;21:1283-309.

20. Kramer IRH, Pindborg JJ, Shear M. Histological typing of odontogenic tumors (2nd ed). B erlin: Springer-V erlag 1991;31.
21. Liu B, Y u SF, L i TJ. M ultinucleated giant cells in various forms of giant cell containing lesions of the jaws express features of osteoclasts. J Oral Pathol Med 2003;32(6):367-75.

22. B haskar NS, Cutright DE, B easley JD, Pérez B. Giant cell reparative granuloma (peripheral): Report of 50 cases. J Oral Surg 1971;29:110-15.

23. Eversole $L F$, Rovin $S$. Reactive lesions of the gingiva. J Oral Pathol 1972;1:30-38.

24. Small GS, Rowe NH. A true giant cell tumor in the mandible. J Oral Surg 1975;33:296-301.

25. Thompson SH, Bischoff $P$, Bender $S$. Central giant cell granuloma of the mandible. J Oral Maxil Surg 1983;41(11): 743-46.

26. O da D. A Iternative treatment for central giant cell reparative granuloma. A dv A nat Pathol 2003;10(2):110.

27. K urtz M, M esa M, A lberto P. Treatment of a central giant cell lesion of the mandible with intralesional glucocorticosteroids. Oral Surg Oral Med Oral Pathol Oral Radiol Endod 2001;91(6):636-37.

28. K aban M L B, Troulis M J, Ebb D, et al. A ntiangiogenic therapy with interferon alpha for giant cell lesions of the jaws. J O ral M axillofac Surg 2002;60(10):1103-11.

29. Pogrel MA, Regezi JA, Harris ST, Goldring SR. Calcitonin treatment for central giant cell granulomas of the mandible: Report of two cases. J Oral Maxillofac Surg 1999;57(7): 848-53.

30. K aban LB, M ulliken JB, Ezekowitz RA, et al. A ntiangiogenic therapy of a recurrent giant cell tumor of the mandible with interferon alfa-2a. Pediatrics 1999;103:1145-49. 